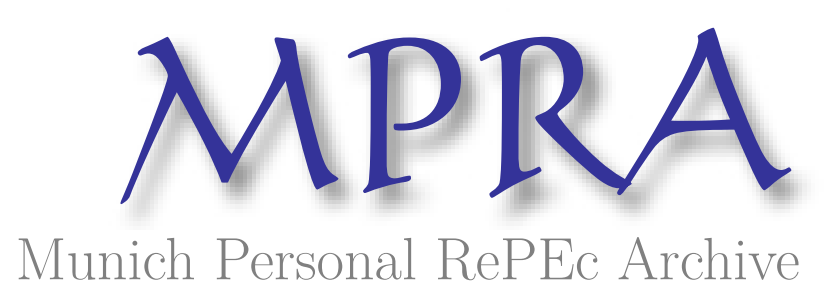

\title{
What Role Did Rising Demand Play in Driving Food Prices Up?
}

Sen Gupta, Abhijit and Bhattacharya, Rudrani

Asian Development Bank, National Institute of Public Finance and Policy

2016

Online at https://mpra.ub.uni-muenchen.de/79704/

MPRA Paper No. 79704, posted 14 Jun 2017 21:38 UTC 


\title{
What Role Did Rising Demand Play in Driving Food Prices Up?*
}

\author{
Rudrani Bhattacharya ${ }^{\dagger}$ \\ Abhijit Sen Gupta ${ }^{\ddagger}$
}

\begin{abstract}
Average food inflation in India during the period 2006-2013 was one of the highest among emerging market economies, and nearly double the inflation witnessed in India during the previous decade. An often cited hypothesis argues that the surge in food inflation during this period was driven by rising demand for high-value food products due to higher per capita income and diversification of Indian diets. In this paper we test the validity of this hypothesis by estimating the expenditure elasticity and then calculating the aggregate demand using data from household survey conducted by the National Sample Survey Organisation (NSSO). Our results show that in recent years estimated demand has exceeded supply of all major food products, barring fruits. Moreover, empirical estimates indicate that the demand supply gap is an important driver of rise in food prices, along with other factors such as minimum support prices, global prices, fiscal deficit and agricultural wages.
\end{abstract}

JEL Classification: E31; E37 and Q11

Keywords: Food Inflation, Engel Curves, QUAIDS Model, India

\footnotetext{
* The authors would like to thank Laurence Ball, Charan Singh and conference participants of International Conference on Food Price Volatility: Causes and Challenges, Rabat, Morocco for their very helpful comments. The authors also express thanks to an anonymous referee for insightful comments. The views expressed in this article are the views of the authors and do not necessarily reflect the views or policies of the Asian Development Bank (ADB), or its Board of Governors, or the governments they represent.

$\dagger$ Assistant Professor, National Institute of Public Finance and Policy, New Delhi. Email:rudrani@nipfp.org.in

‡ Economist, India Resident Mission, Asian Development Bank, New Delhi, Email:asengupta@adb.org
} 


\section{Introduction}

India experienced one of the highest rates of food inflation among emerging economies during the period 2006 to 2013. The average rate of inflation in food products in India was more than 9\% during this period. Moreover, the rate of increase in food prices during this period was nearly double that witnessed in the previous decade. While India has witnessed sporadic spurts in food inflation, episodes of such persistently high food inflation have been rare.

The welfare impact of such high rate of food inflation is bound to be significant given that food constitutes a significant share of the consumption basket of the Indian households. According to the report on Household Consumption Survey by the National Sample Survey Organisation (NSSO), in 2011-12, on average, food accounts for $48.6 \%$ of overall expenditure in rural areas and $38.5 \%$ in urban areas. The proportion is significantly higher for 269 million people, or $21.9 \%$ of the total population, who live in abject poverty. On average, the bottom three expenditure deciles in rural areas devote $60.4 \%$ of their total expenditure on food products while in urban areas the share is $56.5 \%$. Given that this section already spends a large proportion of their income on food, they are generally unable to divert additional expenditure on food to neutralise the impact of food inflation, thereby aggravating food and nutrition deficiency.

A variety of reasons have been put forward to explain the rise in food prices in this period. Cost escalation factors including rise in price of inputs such as agricultural wages and fuel have been identified as major drivers of surge in food prices. A sharp rise in minimum support prices during these years also contributed to food inflation, given that these prices act as floor to market price. Negative production shocks such as the drought in 2009, and low production growth in 2008-09 also propped up agricultural prices. Lax monetary and fiscal policy as well as policies related to stocking and futures trading and temporary trade policies have also contributed to rising food inflation.

Apart from these factors, an often cited structural factor resulting in rising food prices in India is the increase in demand for various food products due to rising per-capita income and population growth that was not matched by a commensurate increase in supply due to low productivity. In fact, rising per-capita income in emerging economies like India and China, and the associated rise in demand for food, has been pointed out as a driver of global spike in food prices. Krugman (2008) points out that the rise in per-capita income in emerging markets has shifted the dietary habits towards meat, which in turn has raised the demand for grains as animal feed. Similarly, Wolf (2008) argues that the shifts in land use in response to rising demand for meat and related animal feed has reduced the supply of cereals available for human consumption.

Studies focusing on food inflation in India have stressed the importance of rising demand of various food products playing a role in driving food prices up. Mishra and Roy (2012) argue the rising demand supply mismatch contributed to food inflation for all commodities, barring cereals. Kumar et al. (2010) also argue that the rising inequality in per-capita income resulted in rise in demand for food products, which in turn led to a a price rise.

Similarly, Gokarn (2011), Bandara (2013), Gulati and Saini (2013) also point out that India has witnessed shifts in its food basket from cereals to protein and vitamin-rich diets, such as pulses, milk, vegetables, egg, meat and fish causing upward pressure on prices of these commodities. In contrast, Eapen and Nair (2012) argue that there 
is little evidence supporting the view that a consumption shift towards high value agriculture products has been driving prices up, except in the case of milk.

A few papers have conducted empirical analysis to identify the primary drivers of food inflation in India. For example Agrawal and Kumarasamy (2012), argue that demand supply gap has resulted in food inflation in India. They forecast the demand for various food products by using an Auto Regressive Distributive Lag (ARDL) model, and estimate income elasticity, cross-price elasticity and own price elasticity, as well as point out supply side measures that should be put in place to control food inflation. Similarly, Sasmal (2015) develops a two sector general equilibrium model to conclude that food price inflation will exist in an economy where demand for food products increases at a higher rate in a growing economy but growth in agricultural production lags behind. Empirical evidence suggests that increase in per capita income has a significant positive impact on food prices while there is a negative longrun relationship between food grains production and food prices. Using a panel of three South Asian economies, Carassco and Mukhopadhyaya (2012) find that rising per capita income has a positive impact on food prices, while a rise in agricultural production negatively impacts food prices, with the extent of impact being different in the various countries.

Our paper adds to the existing literature in a couple of ways. Firstly, we use the Quadratic Almost Ideal Demand System (QUAIDS) model to estimate the demand for key important commodities. ${ }^{12}$ The application of the QUAIDS model allows us to make use of household consumption data to estimate income elasticities for various food products, and thereby assess the evolution of demand of various commodities over time. Thus the application of QUAIDS model significantly improves the modeling of consumption behavior compared to studies that have used aggregate consumption as a proxy for underlying demand in the economy. Secondly, the use of the QUAIDS model allows us to calculate the demand supply gap explicitly, and estimate the impact of this gap on food prices, after controlling for other major determinants of price rise. This is again in contrast to most of the existing studies that have looked separately at the impact of demand (proxied by per capita income) and the impact of supply (proxied by volume of agriculture production or production of food grains). Finally, we use the 2009-10 household survey data to compute the elasticities, with the survey period falling right in the middle of the high inflation years in India, and thereby providing us with important insights on how the change in consumption behavior during this period has influenced food prices. Most of the existing studies including Mittal (2010) and Kumar et al. (2011) have used data from surveys up to 2004-05 to estimate demand for food products in India.

The rest of the paper is structured as follows. Section 2 describes the change in consumption pattern over a 25-year period and across consumption expenditure deciles. Section 3 describes the model used to calculate the expenditure elasticities for various food products, evolution of the demand for these products with rising per capita income, and the resulting demand supply gap. In Section 4, we estimate the extent to which this gap was responsible for a rise in food prices. Finally, Section 5 concludes by summarizing the main findings of the paper.

\footnotetext{
1 The QUAIDS model has been primarily used to estimate future demand for various commodities (Mittal 2010) and Xie et al (2004).

2 Xie et al (2004) points out that the QUAIDS model has several advantages in modeling consumption behavior for grouped commodities including approximating any demand system arbitrarily to first-order, aggregating perfectly over consumers, satisfying the axioms of choice, and capable of testing the restrictions of homogeneity and Slutsky symmetry. The inclusion of the quadratic term in log income helps capturing the effects of non-linear Engel curves, as observed in various empirical demand studies.
} 


\section{Evolution of Food Products' Consumption}

The National Sample Survey Organisation conducts a survey of consumer expenditure at regular intervals. We use data from these surveys to document the trend in share of household consumption on various food items since the late 1980s in Figure 1. We concentrate on six major food products viz. cereals, pulses, milk, eggs, meat and fish, fruits and vegetables. It is evident that there has been a steady decline in the share of income spent on consuming food both in rural and urban areas. Between 1993-94 and 2011-12, the share of expenditure on food fell by 14.6 percentage points in rural areas and 16.1 percentage points in urban areas. During this period, the real monthly per capita expenditure (MPCE) grew by an average annual rate of $1.8 \%$ in rural areas and $2.3 \%$ in urban areas, implying that higher MPCE was associated with a drop in share of food in the consumption basket. Thus the evidence corroborates Engel's Law, which argues that expenditure share dedicated to food consumption declines as income (here proxied by expenditure) rises.

Figure 1: Share of Food Expenditure in Monthly Per Capita Expenditure
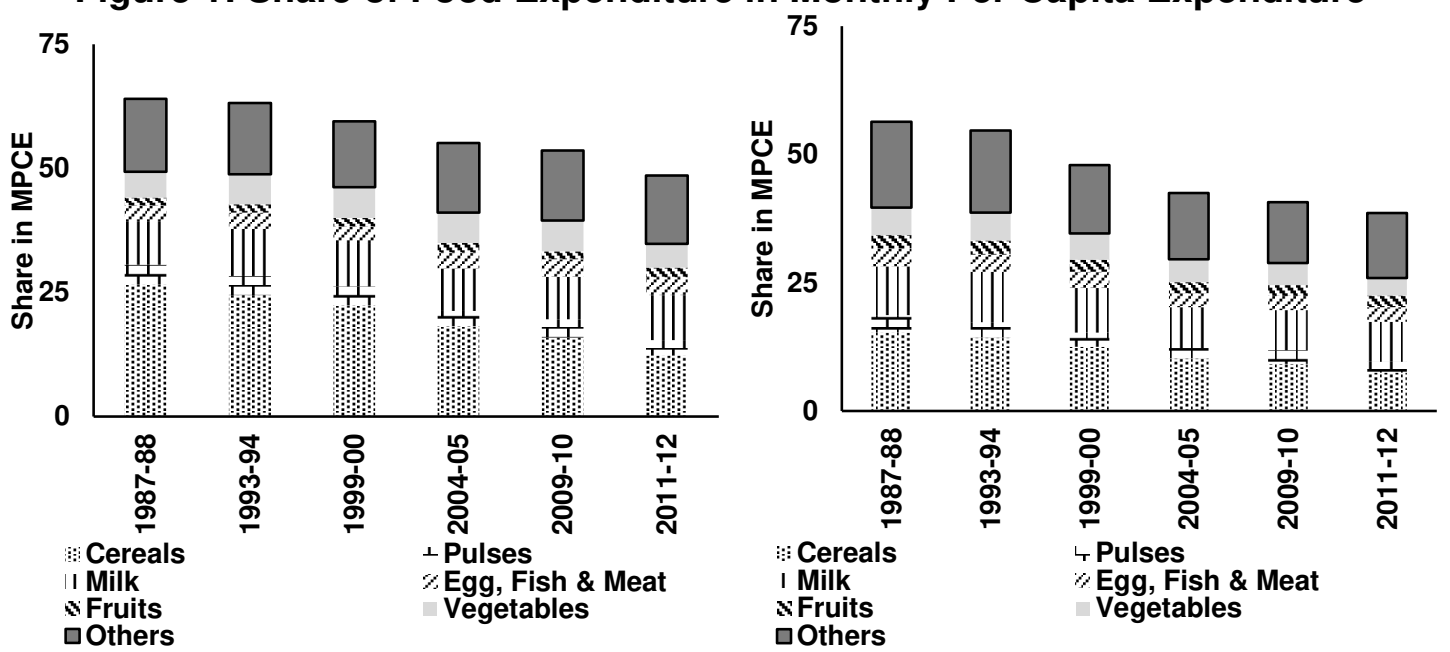

Source: National Sample Survey Organisation, various reports

Despite a secular decline in the proportion of expenditure on food, within food expenditure, spending on selected food products witnessed an increase. While share of expenditure on cereals witnessed the biggest decline in rural and urban areas, in the case of pulses and vegetables there was a decline in urban areas only. In contrast, a higher share of income was spent on milk, fruits and eggs, meat and fish, providing support to the hypothesis that consumption of protein and vitamin rich agriculture products have increased.

Cross-sectional data from the household consumer expenditure survey of 2011-12 also validate a faster increase in consumption of protein and vitamin rich agricultural products such as milk, fruits and eggs, fish and meat relative to staples such as cereals and pulses. Figure 2 plots the household MPCE of six major food items across consumption deciles. For the rural households, the ratio of average consumption of the top two expenditure deciles to that of the bottom two deciles at 9.8 is highest for fruits. This is followed by milk at 7.4 and eggs, and meat and fish at 4.2. In contrast, the ratio is less than 2.0 for cereals, pulses and vegetables.

A similar pattern is observed in the case of urban consumers where the ratio is again highest for fruits followed by milk and eggs, meat and fish. The ratio remains below 2.0 for cereals and pulses, while it is 2.2 for vegetables. Thus increases in household 
income are associated with a significantly larger incremental expenditure on fruits, milk and eggs, meat, fish relative to cereals, pulses and vegetables.

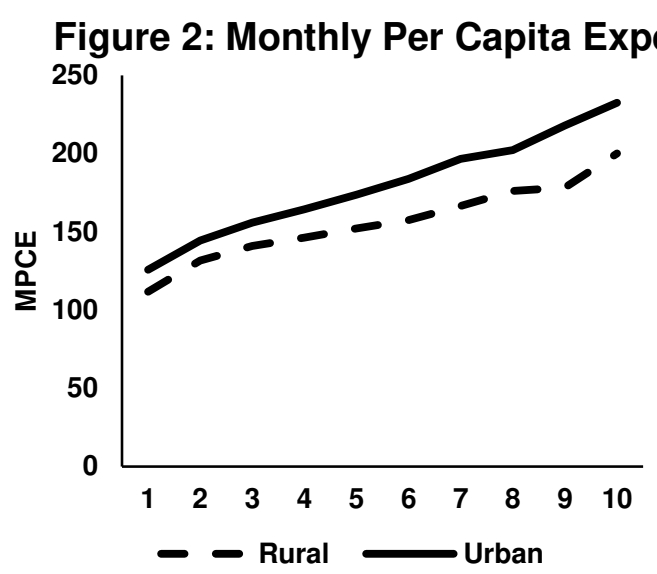

(a) Cereals

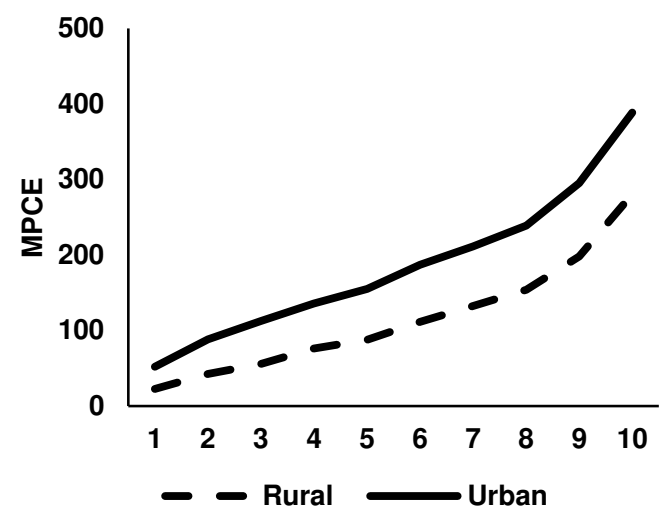

(c) Milk

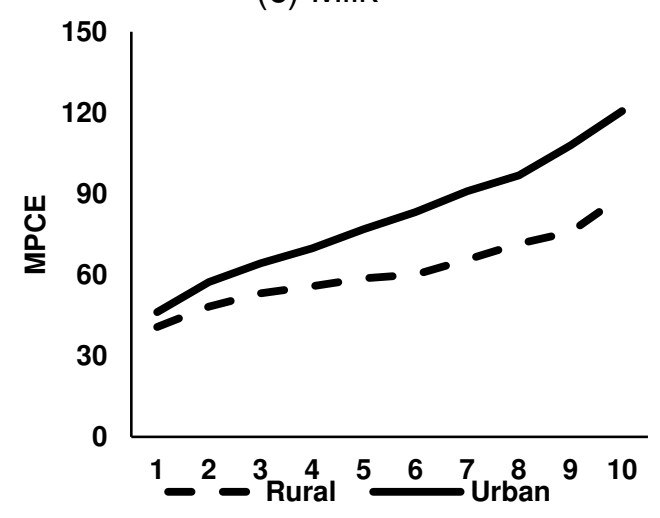

(e) Vegetables

Source: National Sample Survey Organisation

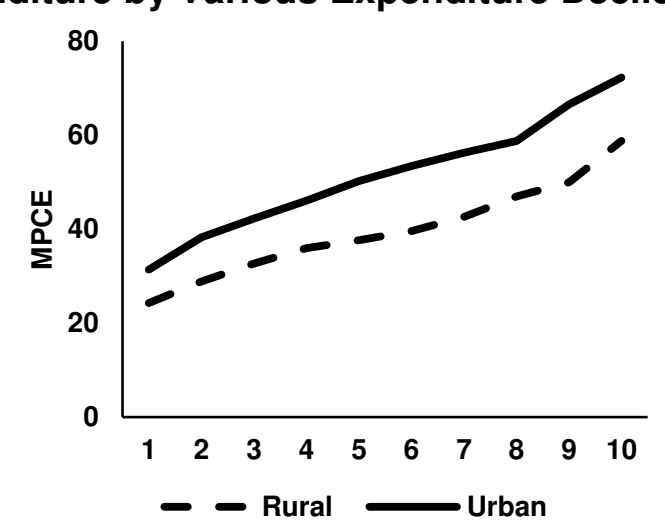

(b) Pulses

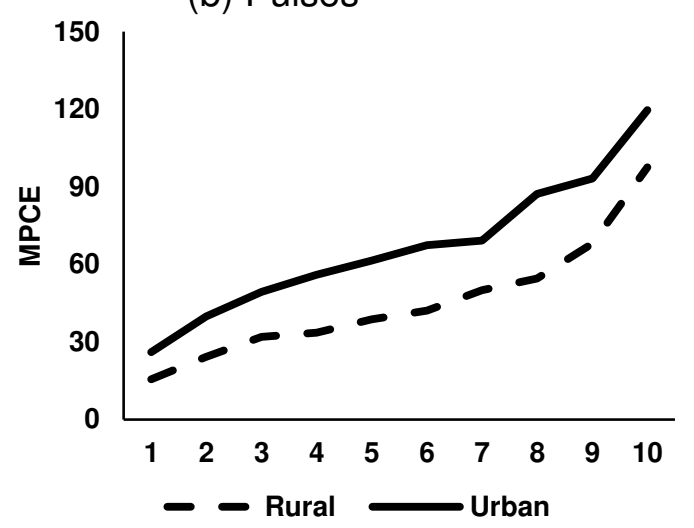

(d) Eggs, Meat and Fish

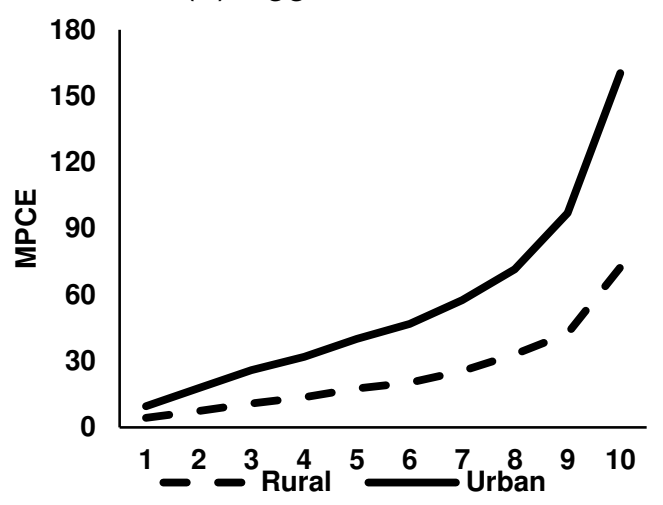

(f) Fruits

\section{Estimating Demand Supply Gap for Food Commodities}

Having corroborated a dietary shift towards products, which have contributed significantly to the food inflation in recent years, we focus on the change in aggregate demand resulting from this shift in diet. We estimate expenditure elasticity of the above selected food items using household consumer data. We cover the period from 2004-05 to 2013-14. During this period three large household surveys were conducted in 2004-05, 2009-10 and 2011-12. Given the risk expenditure elasticities can change over a period of time, we use the data from 2009-10 household survey to compute these elasticities to mitigate this risk. Given the possibility of expenditure elasticities changing over a period, we use the data from 2009-2010 
household survey to compute these elasticities to mitigate the errors arising from this. The six selected food items comprise $76 \%$ of average MPCE.

We compute aggregate demand as the sum of aggregate household demand and indirect demand requirements from industries using these food items as inputs (seed, feed and wastage [SFW]). We estimate per capita household demand and associated expenditure elasticities for the selected food items using the Quadratic Almost Ideal Demand System (QUAIDS) following Banks et al. (1997). For India, Mittal (2010) have also used the QUAIDS model to estimate the expenditure elasticity in India. However, the elasticities computed in Mittal (2010) are based on household expenditure data from surveys conducted till 1999-2000. We use more recent survey data to compute these elasticities, to accurately capture the role played by rising demand in influencing food prices.

The QUAIDS are specified with expenditure shares as the dependent variable. A household's expenditure share for good $i$ is defined as $w_{i}=\frac{p_{i} q_{i}}{m}$, where $p_{i}$ is the unit price of good $i$ and $q_{i}$ is the quantity of good $i$ purchased or consumed and $m$ is the total expenditure on all goods in the demand system. With this definition of $m$,

${ }_{i=1}^{K} w_{i}=1$, where $\mathrm{K}$ is the number of goods in the system. The functional form of the expenditure share under QUAIDS is as follows:

$$
w_{i}=\alpha_{i}+\sum_{j=1}^{K} \gamma_{i j} \ln p_{j}+\beta_{i} \ln \left\{\frac{m}{P(p)}\right\}+\frac{\lambda_{i}}{b(p)}\left[\left\{\frac{m}{P(p)}\right\}\right]^{2}
$$

where $p$ is the vector of all prices and $b(p)$ is defined as $b(p)=\prod_{i=1}^{K} p_{i}{ }^{\beta_{i}}$. The aggregate price index is defined as

$$
\ln P(p)=\alpha_{0}+\sum_{i=1}^{K} \alpha_{i} \ln p_{i}+\frac{1}{2} \sum_{i}^{K} \sum_{j}^{K} \gamma_{i j} \ln p_{i} \ln p_{j}
$$

The parameters are subject to the following restrictions

$$
\sum_{i}^{K} \alpha_{i}=1 ; \sum_{i}^{K} \beta_{i}=0 ; \sum_{i}^{K} \gamma_{i j}=0 \forall j
$$

and Slutsky symmetry implies that $\gamma_{i j}=\gamma_{j i}$. The estimated expenditure elasticities for the selected food items are given in Table 1.

Table 1: Expenditure Elasticity

\begin{tabular}{|l|c|}
\hline & Elasticities \\
\hline Cereals & 0.226 \\
Pulses & 0.515 \\
Vegetables & 1.535 \\
Fruits & 2.21 \\
Milk and Milk Products & 2.185 \\
Meat and Fish & 0.796 \\
\hline
\end{tabular}

Source: Authors' estimates

Table 1 shows that expenditure elasticities for selected major food items are found to be positive, suggesting a rise in total household expenditure would lead to stronger demand for these items. Expenditure elasticities for milk and milk products, vegetables and fruits are over one, suggesting that a $1 \%$ increase in household expenditure on food would lead to a more than $1 \%$ increase in the demand for these 
items. The elasticity for meat and fish, although below unity, is high enough to cause significant rise in demand for these items as total expenditure on food increases. Compared to Mittal (2010), our elasticities are higher for cereals, vegetables and fruits, and lower for pulses, meat and fish.

We compute aggregate household demand using the following equation:

$$
D_{i, t}^{H}=d_{i, 0} N_{t} \prod_{n=1}^{t}\left(1+g_{n} * e_{i}\right)
$$

where $D_{i, t}^{H}$ is the aggregate household demand for commodity $i$ in year $t, d_{i, 0}$ is the per capita demand for commodity $i$ in the base year, $N_{t}$ is the population in year $\mathrm{t}$, $g_{n}$ is the per capita income growth rate in year $n$ where $n$ goes from 1 to t, and $e_{i}$ is the expenditure elasticity for the commodity $i$. We generate a historical household demand series for the period from 2004-05 to $2013-14 .^{3}$

We compute aggregate demand using the following equation:

$$
D_{i, t}=\frac{D_{i, t}^{H}}{1-x_{i}}
$$

where $D_{i, t}$ is the aggregate demand for commodity $i$ in year $t$ and $x_{i}$ is the share of indirect demand in total demand for commodity $i$. The share of indirect demand in total demand for the selected food products are sourced from the Planning Commission (2012), and are presented in Table 2. The report provides estimates of indirect demand for 2004-05 and 2011-12. We take an average of the estimates for these two periods to compute total demand for 2004-05 to 2013-14. In addition, an average of the indirect demand estimates for rice and wheat given in the report is used as a proxy for indirect demand for cereals.

\section{Table 2: Indirect Demand for Food Products (\% of total demand)}

\begin{tabular}{|l|ccc|}
\hline Commodity & $2004-05$ & $2011-12$ & Average \\
\hline Rice & 12.97 & 13.43 & 13.20 \\
Wheat & 17.08 & 17.69 & 17.39 \\
Cereals & 15.03 & 15.56 & 15.29 \\
Pulses & 37.00 & 41.71 & 39.36 \\
Milk & 40.58 & 41.58 & 41.08 \\
Fish and Meat & 39.45 & 40.83 & 40.14 \\
Vegetables & 37.76 & 38.43 & 38.10 \\
Fruits & 81.47 & 82.90 & 82.19 \\
\hline
\end{tabular}

In Figure 3, we compare the estimated aggregate demand for the selected commodities with the domestic supply during the period 2004-05 to 2013-14 to evaluate the demand-supply gap. We adjust the overall domestic production with post-harvest losses experienced by the various commodities to obtain the domestic supply, available for consumption. Estimates of the losses have been taken from Nanda et al. (2010). These losses reduce the amount available for domestic consumption, and take place during post-harvest on-farm operations, transportation from farm to the next destination and storage at various points in marketing channels for all crops.

\footnotetext{
${ }^{3}$ Since our base year per capita household demand $d_{i, 0}$ is estimated for 2009-10, we generate the historical household demand series from 2004-05 till 2013-14 by iterating equation (4) backward and forward with respect to $d_{i, 0}$. The data for GDP at factor cost at constant 2004-05 prices and population are sourced from RBI.
} 
Figure 3: Estimated Demand Supply Gap in Major Food Products

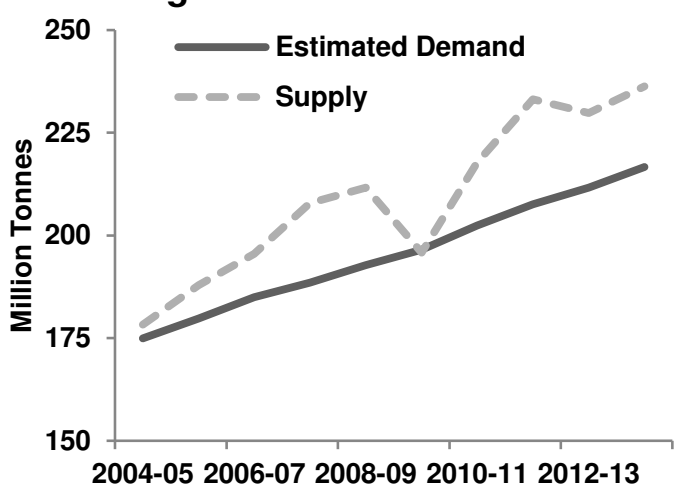

(a) Cereals

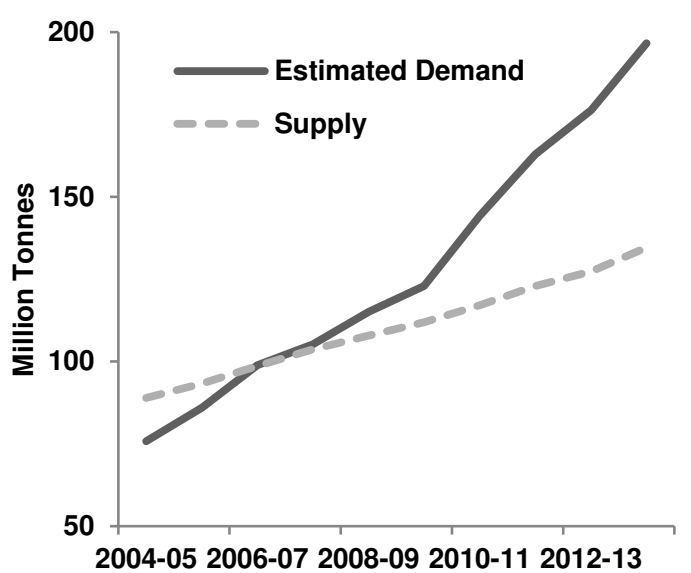

(c) Milk

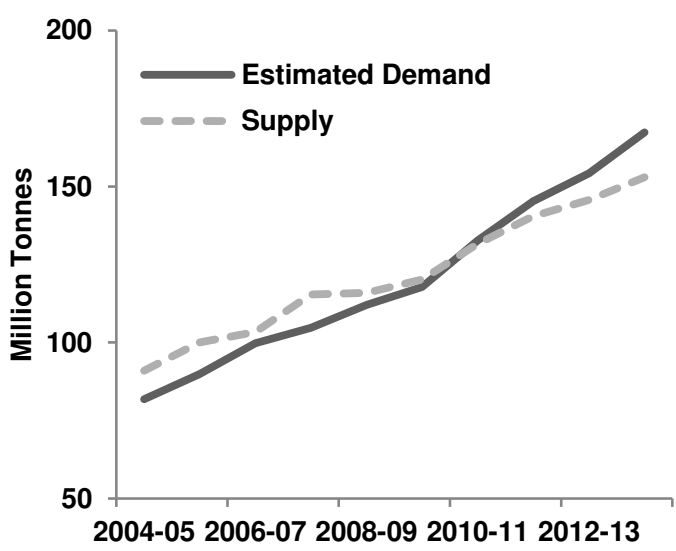

(e) Vegetables

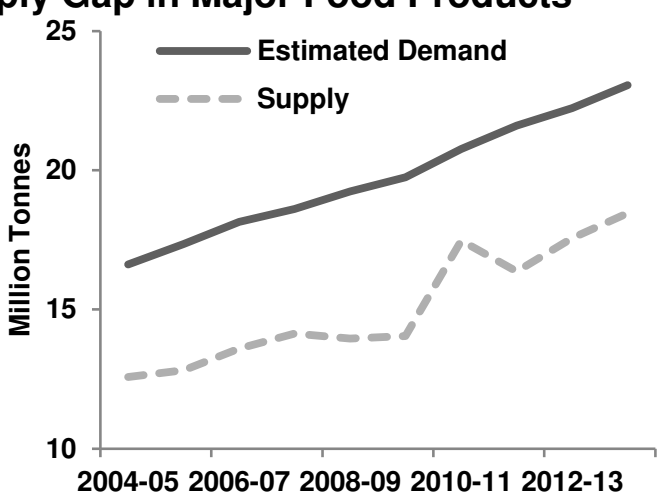

(b) Pulses

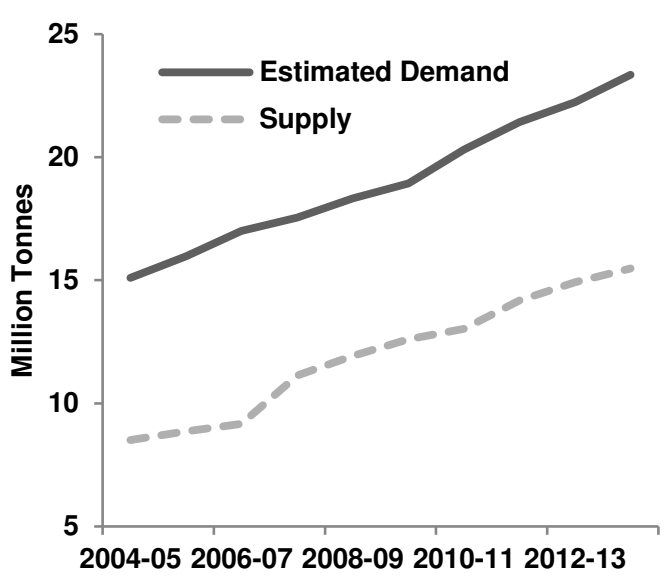

(d) Fish and Meat

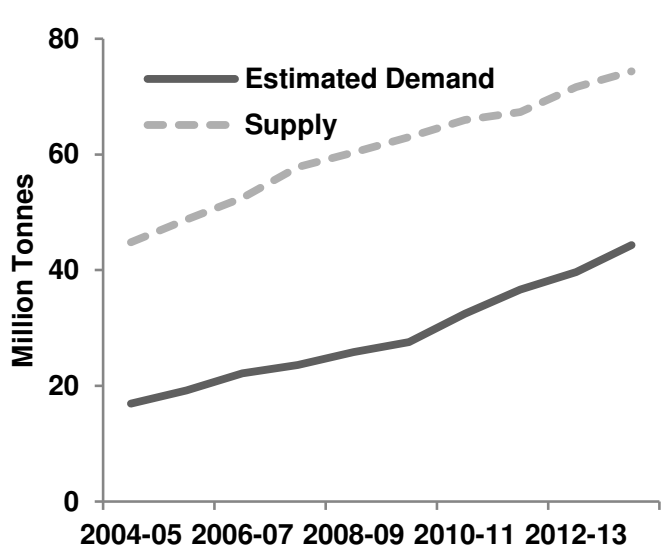

(f) Fruits

Source: National Sample Survey Organisation and Authors' Estimates

For cereals, post-harvest loss adjusted supply has been higher than estimated demand due to healthy production growth between 2004-05 and 2008-09 and again between 2010-11 and 2013-14. It was only in 2009-10, when there was a severe drought that supply fell marginally below estimated demand. In contrast, in pulses, the estimated demand has consistently outstripped supply, and the gap has widened in recent years. This gap has been met to some extent through import of these 
commodities, which in turn makes the domestic price vulnerable to changes in international prices.

In the case of protein rich commodities, milk as well as meat and fish, the high expenditure elasticities has meant that estimated demand has been increasing at a significantly higher rate than supply. Consequently, while supply of milk and milk products was higher than estimated demand in 2004-05, estimated demand outstripped supply in 2008-09, with the gap between estimated demand and supply increasing since then.

In contrast, in the case of meat and fish, estimated demand exceeded supply by 6.5 million tonnes even in 2004-05. Since then the gap between the two has been steadily rising with the difference amounting to nearly 8 million tonnes in 2013-14.

As can be seen from Table 2, both fruits and vegetables exhibit expenditure elasticities, which are greater than one, implying a more than a proportionate increase in demand for these products for a given increase in expenditure. In case of vegetables, while aggregate supply exceeded estimated demand by 24.3 million tonnes in 2004-05, the gap between the two had closed by 2010-11, and in recent years estimated demand has outstripped supply. In case of fruits, despite the high expenditure elasticity, we find domestic supply has been higher than estimated demand throughout the entire period. Thus factors other than demand supply gap explain the rapid surges in fruit prices in recent years.

It is evident that shortfall in production has resulted in demand pressure for a number of commodities such as pulses, milk, fish and meat and vegetables. The shortfall in production has been driven by limited gains in agricultural productivity in recent decades, with the latter in turn being driven by a myriad of factors including fragmented land holdings, outdated farming techniques, inadequate use of modern inputs, declining share of public investment in agriculture and rising share of subsidies, and lack of organized agricultural marketing.

\section{Did Rising Demand Supply Gap Contribute to Food Inflation?}

We now turn our focus to whether the gap between demand and supply for the various commodities contribute to a rise in prices in India as has been claimed in a number of studies. We empirically estimate the impact of a demand supply gap on food prices after controlling for some of variables found in the literature to have affected food prices. We focus on six food products described in Section 3 i.e. cereals, pulses, milk, meat and fish, vegetables and fruits. Data on various food product prices are sourced from the WPI series available with the Office of the Economic Advisor, Ministry of Commerce and Industry, while data on demand supply gap, the main variable of interest, is calculated in Section 3.

Other factors, which have been found to impact food prices, include global prices of various food commodities, minimum support prices, agricultural wages and fiscal deficit. ${ }^{4}$ Transmission of international prices to domestic retail prices could be a major factor driving inflation, especially given the surge in international prices of food commodities in 2008 , and again in 2010. The high inflation during this period was driven by surge in prices of cereals, edible oils, sugar and some dairy products. Some of this rise in global prices is likely to have transmitted to domestic shores, given that the extent of agricultural sector's integration with global market, calculated as the share of agriculture trade to agriculture GDP increasing nearly four folds from

\footnotetext{
${ }^{4}$ For a detailed review of the literature discussing factors driving food prices in India, please refer to Mishra and Roy (2012).
} 
$5.2 \%$ in 1990-91 to around $19 \%$ in 2013-14. India has been a net exporter of foodgrains during the last three decades, while imports are limited to edible oils, sugar and pulses. Table 3, highlights the extent of comovement between domestic and global inflation rates during 2005 to 2014, and indicates that only in the case of sugar and edible oils, there was significant positive comovement between the two.

\section{Table 3: Extent of Comovement between Global and Domestic Price Changes}

\begin{tabular}{|l|c|}
\hline Product & Co-movement \\
\hline Food & -0.0883 \\
& $(0.3373)$ \\
& -0.1047 \\
Deat & $(0.2553)$ \\
& 0.0904 \\
& $(0.3261)$ \\
Cereals & -0.0386 \\
& $(0.6753)$ \\
Edible Oils & $0.6380^{\star * *}$ \\
& $(0.0000)$ \\
Sugar & $0.5634^{* * *}$ \\
& $(0.0000)$ \\
\hline \multicolumn{2}{|c|}{ Note: ${ }^{* * *},{ }^{* *}$, and ${ }^{*}$ imply significance at $1 \%, 5 \%$} \\
and 10\% respectively. \\
Source: FAOSTAT and Office of Economic \\
Advisor, Ministry of Commerce.
\end{tabular}

Rise in global price of a commodity can affect its domestic price through trade channel, subject to trade policies. When global price of a commodity rises, exporters find it more attractive to supply in the global market, causing lower supply in the domestic market, followed by a rise in domestic prices. The extent of the impact on domestic supply and the resultant effect on domestic price of the commodity will depend on the extent of tradability of the product, as well as short run trade policy responses to global price hike, such as, export ban etc. Secondly, surge in global price of a commodity, if it is included in the import basket of the consumers, raises the price of its domestic substitute via expenditure switching channel. Again, the extent of transmission of global price rise into its domestic counterpart of a commodity depends on whether the domestic price is administered or not.

For instance, India is the largest milk producer in the world, contributing to $17 \%$ of the global milk production (Rajeswaran et al, 2014). However, the large spikes observed in global milk prices do not seem to get transmitted to domestic milk prices (Bhattacharya and Sen Gupta, 2015). The Indian milk and dairy industry is highly segmented with Gujarat Cooperative Milk Marketing Federation (GCMMF) being the largest organized player in the dairy sector and the largest exporter in the country (Rajeswaran et al, 2014). The study finds that the price of milk paid by GCMMF, which can be taken as a proxy for farm gate price of milk, is found to have seen sharp rise in post 2006 period in the backdrop of sharp rise in exports of skim milk powder in response to rise in global milk prices, and the rapid depletion of its domestic buffer stock. In the pre 2006 period, maintenance of buffer stock along with ban on exports of skim milk powder in India have been used as a tool to moderate domestic milk prices. In this scenario, occasional export ban on skim milk powder and building of domestic buffer stock have been adopted again in post 2006 period, which eventually moderated the transmission of spikes in global milk prices to its domestic counterpart. This indicates that a part of the milk prices in India is administered and its dynamics can vary in response to global price changes, exogenously to trade channel. 
A rise in minimum support price (MSP) also fuels food inflation, given that it is meant to be the floor price for various crops i.e. the minimum price at which the government stands to procure crops from farmers. The wholesale prices are typically higher than these floor prices, and if the floor price keeps rising, as has been the case in India, it leads to a rise in wholesale prices as well. Figure 4 shows that the weighted average of annual inflation in minimum support prices (WPI weights) during the period 200708 to $2012-13$ was $13.0 \%$ compared to only $3.9 \%$ during the preceding four years. This was associated with WPI inflation in these products increasing from $3.7 \%$ to $10.1 \%$. Subsequently, when MSP inflation fell to an average $3.8 \%$ in $2013-14$ and 2014-15, it corresponded with WPI inflation declining to 3.3\%. The data on crop wise MSP is compiled from Ministry of Agriculture. In the case of vegetables, fruits, milk and meat and fish, for which there is no MSP, we set the MSP at zero.

\section{Figure 4: Relationship between Minimum Support Price and Wholesale Price Inflation}

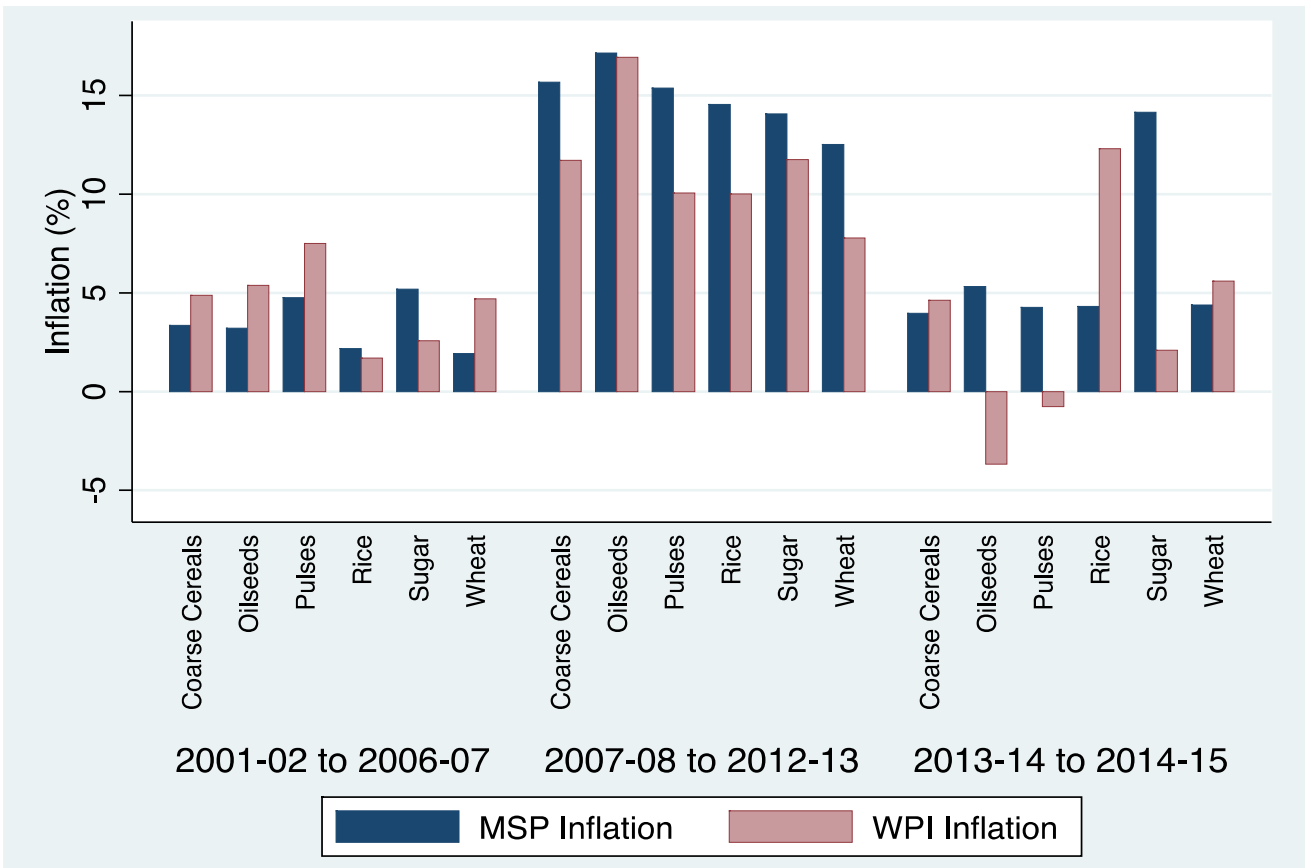

Source: Ministry of Agriculture and Office of Economic Advisor, Ministry of Commerce.

Sharp increase in rural wages, by raising the cost of production, can push up food prices. Alternately, by providing a higher purchasing power, higher wages can bolster the demand for food items. Agricultural wages grew by an average annual rate of $17.3 \%$ between 2008-09 and 2012-13, nearly four times higher than the average annual growth between 2003-04 and 2007-08 (Figure 5). Moreover, during the latter period, the rise in agricultural wages was considerably higher compared to nonagricultural wages, which grew at an average rate of $15.6 \%$. The introduction and the subsequent expansion of the National Rural Employment Guarantee Scheme, which guarantees 100 days of wage employment, have been postulated as driving rural wages up. However, the empirical evidence indicates that the impact is limited. While Imbert and Papp (2015) find that NREGA raised wage income by $4.5 \%$, Berg et al (2012) argue that the boost to daily wages was 5.3\%. Data on agricultural wages are taken from the Database on the Indian Economy, Reserve Bank of India. 
Figure 5: Wage Inflation and Food Inflation

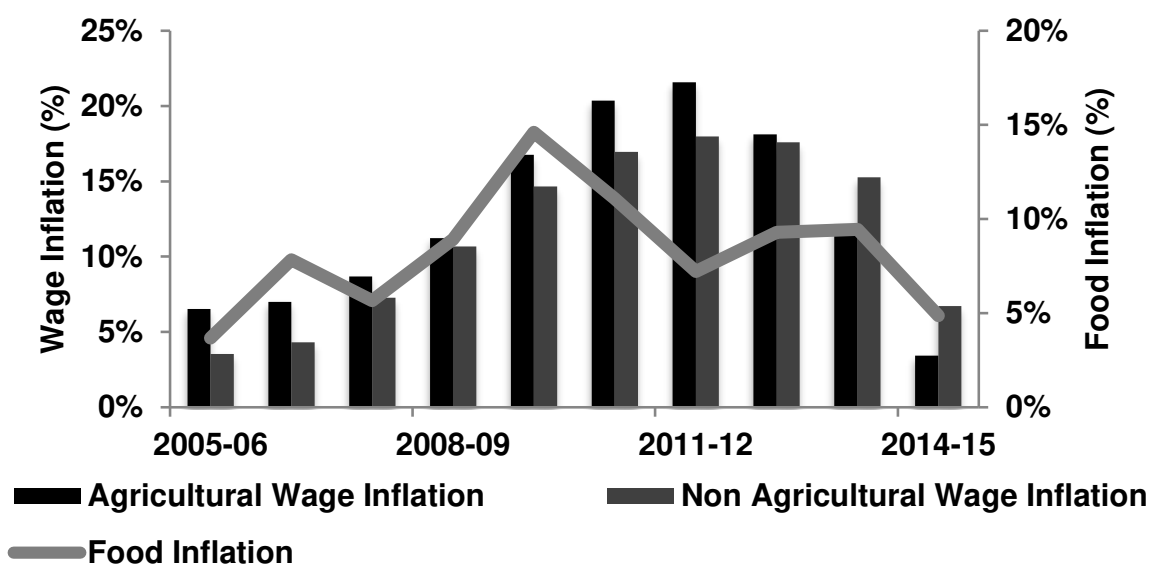

Source: Labour Bureau and Office of Economic Advisor, Ministry of Commerce.

Finally, the link between fiscal deficit and inflation has been extensively explored in the literature from several perspectives. The first argument is based on the rationale that in developing economies with low tax base and tax evasion, fiscal deficit is financed by borrowing from the banking system (Dornbusch et al. (1990) and Sargant and Wallace (1981)). This in turn results in higher money growth leading to high inflation. A second argument points out that high level of deficit may lead to higher demand, which will raise prices of products whose output can not be immediately increased. For India, Gulati and Saini (2013) find fiscal deficit to be the biggest driver of food inflation.

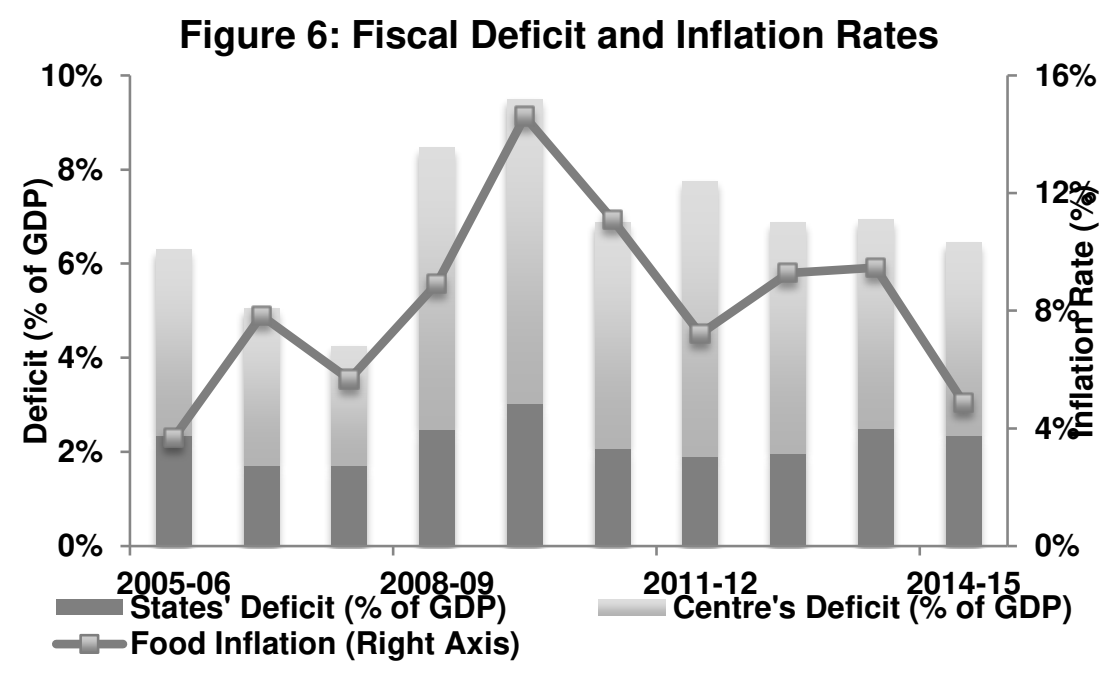

In Table 4, we examine the relationship between commodity prices and the demandsupply gap in these commodities in a panel regression framework for the period 2004-05 to 2013-14. The regression specification is outlined as

$$
Y_{i, t}=\alpha_{i}+\beta X_{i, t}+\gamma Z_{i, t}+\mu_{i, t}
$$

where i refers to the different food products viz. cereals, pulses, milk, fruits, vegetables and meat and fish and t represents the time period. We use the fixed 
effects estimator accounting for heteroskedasticity. Here $Y$ is the dependent variable, measured as change in food product prices. Among the explanatory variables, $X$ is the main variable of interest, i.e. demand supply gap for various food products while $Z$ is a vector of other variables found in the literature to have influenced food prices including minimum support prices, global prices, fiscal deficit as a percentage of GDP and agricultural wage growth. While column (I) focuses on the relationship between demand-supply gap and food prices, in columns (II) - (V), we control for other factors. Initially, we introduce these factors one at a time, to evaluate their role in determining food prices. In column (VI), we focus on the various major drivers of food prices under one specification. The summary statistics of the different variables are given in Table $A 1$ in the Appendix

Table 4: Effect of Demand Supply Gap on Food Prices

\begin{tabular}{|c|c|c|c|c|c|c|}
\hline & I & II & III & IV & V & VI \\
\hline Constant & $\begin{array}{c}5.047^{\star \star *} \\
{[133.856]}\end{array}$ & $\begin{array}{l}3.578^{\star \star \star} \\
{[13.057]}\end{array}$ & $\begin{array}{c}0.557 \\
{[1.321]}\end{array}$ & $\begin{array}{l}4.634^{\star \star *} \\
{[28.108]}\end{array}$ & $\begin{array}{l}4.603^{* * *} \\
{[84.904]}\end{array}$ & $\begin{array}{c}3.731^{\star \star \star} \\
{[7.994]}\end{array}$ \\
\hline Demand Supply Gap & $\begin{array}{c}0.011^{\star * \star} \\
{[3.4301}\end{array}$ & $\begin{array}{c}0.013^{* * *} \\
{[4.769]}\end{array}$ & $\begin{array}{c}0.006^{* * *} \\
{[2.946]}\end{array}$ & $\begin{array}{l}0.009^{* *} \\
{[2.561]}\end{array}$ & $\begin{array}{l}0.006^{* * *} \\
{[2.7141}\end{array}$ & $\begin{array}{l}0.003^{\star *} \\
{[2.188]}\end{array}$ \\
\hline Minimum Support Prices & & $\begin{array}{c}0.884^{\star \star *} \\
{[5.395]}\end{array}$ & & & & $\begin{array}{c}0.070 \\
{[0.643]}\end{array}$ \\
\hline Global Prices & & & $\begin{array}{l}0.901^{\star * *} \\
{[10.594]}\end{array}$ & & & $\begin{array}{c}0.172 \\
{[1.554]}\end{array}$ \\
\hline Fiscal Deficit (\% of GDP) & & & & $\begin{array}{l}0.052^{\star *} \\
{[2.311]}\end{array}$ & & $\begin{array}{c}-0.013 \\
{[-1.337]}\end{array}$ \\
\hline Agricultural Wages & & & & & $\begin{array}{c}0.035^{\star * *} \\
{[9.097]}\end{array}$ & $\begin{array}{c}0.031^{* * *} \\
{[7.522]}\end{array}$ \\
\hline
\end{tabular}

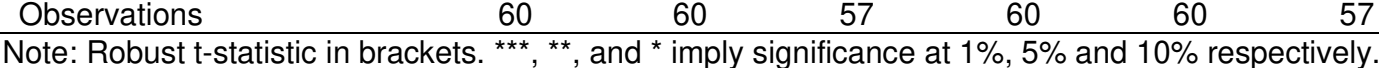

Source: Author's calculations.

We find the demand supply gap has a significant and positive impact on food prices across all the specifications, although there is considerable variation in the size of the coefficient. Thus the results indicate that even after controlling for factors that have been found in the literature to drive food inflation up, demand supply gap has a positive impact on food prices. An additional gap of 1 million tonnes in demand for food and supply of food would result in food prices increasing by $0.3 \%$ to $1.3 \%$ annually.

Turning to other drivers, we find that each is positive and statistically significant when introduced one at a time. The results suggest that an increase in global prices, minimum support prices, fiscal deficit (\% of GDP) and faster wage growth, has a positive and significant impact of food prices. However, when introduced simultaneously, it is only wage growth, which has a significant impact on food prices, apart from demand supply gap.

The channels through which fiscal deficit impacted inflation in India merit some elaboration with the combined fiscal deficit of the state and the central government averaging $7.7 \%$ during the period 2008-09 to 2013-14, compared to an average of $5.7 \%$ in the previous four years. As discussed above, higher fiscal deficit can lead to an uptick in inflation either if the banking system is financing the fiscal deficit or if the resultant higher demand cannot be immediately met with an increase in supply. Evidence suggests that in India the second channel played a more dominant role than the first one. As pointed out in Khundrakpam and Pattanaik (2010), the increased borrowing programme of the government did not result in a high money growth, since the growth in demand for credit from the private sector exhibited significant deceleration. Money supply growth during 2008-09 to 2013-14 averaged $14.8 \%$ well below $19.0 \%$ growth averaged between 2004-05 and 2007-08 while bank 
credit growth to the commercial sector nearly halved from $26.3 \%$ to $15.5 \%$.

The risk to inflation emerged from the fact that the fiscal stimulus measures were primarily aimed at bolstering consumption instead of investment. The measures included waiver of loans to the farmer, liberal increase in the salaries of the government employees, and expansion of a scheme that guaranteed 100 days of employment to a household across entire India. Consequently, the growth in government consumption jumped from $6.6 \%$ during 2004-05 and 2007-08 to $9.2 \%$ between 2008-09 and 2011-12 with the food subsidy bill inching up from $0.65 \%$ of GDP in 2006-07 to over $1.0 \%$ in 2012-13. ${ }^{5}$ These measures boosted aggregate demand, including the demand for food items, which accounts for nearly $46 \%$ of the consumption basket. The increase in food consumption as a result of additional fiscal outlay is over and above the growth in consumption due to change in dietary preferences and per capita income growth.

\section{Conclusion}

The main objective of this article was to empirically examine the often-cited hypothesis that rising per-capita income in emerging markets has shifted the dietary habit towards protein rich commodities, resulting in high food prices. Using household survey data to estimate expenditure elasticity, we find the elasticity to be highest in case of fruits, followed by milk and milk products, vegetables and meat and fish. This has meant that in recent years demand has exceeded supply of all these products, barring fruits. Empirical estimates show that the demand supply gap is an important driver of rise in food prices, along with other factors such as minimum support prices, global prices, fiscal deficit and agricultural wages.

Going forward, high positive expenditure elasticity for protein and vitamin-rich products implies that a rise in per capita income will result rise in aggregate demand for these commodities. This will further widen the demand supply gap in coming years, unless steps are taken to significantly raise productivity of Indian agriculture. Hence, apart from augmenting the supply of various food products, to keep the demand supply gap in check, measures will have to be taken to keep in check other drivers of food inflation.

Indeed, this is what has been observed during the last two years, when in spite of further rise in the demand supply gap for certain commodities, as per capita income increased, food inflation moderated due to improvements in most of the other drivers of food prices. For example, global food prices contracted by an average of $4.7 \%$ in 2013-14 and 2014-15, compared to an increase of 10.8\% between 2006-07 and 2012-13. Similarly, consolidated government deficit (as a percentage of GDP) also improved from around $8 \%$ to below $6.7 \%$. At the same time, the growth in minimum support prices, have significantly reduced from an average annual rate of $12.7 \%$ during 2006-07 and 2012-13 to an average of 3.7\% in 2013-14 and 2014-15. Finally, rural wages, which were growing at an average of 14.6\% during 2006-07 and 201213 , saw its growth decline to sub- $10 \%$ in recent years.

\footnotetext{
${ }^{5}$ In addition, the central bank also attempted to boost aggregate demand, by reducing key policy variables such as the repo rate, statutory liquidity ratio and cash reserve ratio, introducing several refinance windows to provide liquidity and relaxing prudential norms with respect to provisioning and risk weights. For a list of fiscal and monetary measures introduced to boost aggregate demand see Dasgupta and Sen Gupta (2011).
} 


\section{References}

Agrawal, Pradeep and Kumarasamy, Durairaj (2012) "Food Price Inflation in India: Causes and Cures", Institute of Economic Growth Working Paper No. 318.

Bandara, Jayatilleke S. (2013), "What is Driving India's food Inflation? A Survey of Recent Evidence", South Asia Economic Journal, Volume 14 (1), pp.127-156.

Banks, James, Blundell, Richard, and Lewbel, Arthur (1997), "Quadratic Engel Curves and Consumer Demand", The Review of Economics and Statistics, Volume Volume 79 (4), pp. 527-539.

Berg, Erlend Bhattacharyya, Sambit, Durgam, Rajasekhar, and Ramachandra, Manjula (2012), "Can Rural Public Works Affect Agricultural Wages? Evidence from India," CSAE Working Paper Series 2012-05, Centre for the Study of African Economies, University of Oxford.

Bhattacharya, Rudrani. and Sen Gupta, Abhijit, (2015), "Food Inflation in India: Causes and Consequences", National Institute of Public Finance and Policy, Working Paper No. 2015-151.

Carrasco, Bruno and Mukhopadhyay, Hiranya (2012), "Food Price Escalation in South Asia", Economic and Political Weekly, Volume 47(46) pp. 59-70

Dasgupta, Dipak and Sen Gupta, Abhijit (2011), "Rapid Recovery and Stronger Growth after the Crisis", in Mustapha K. Nabli edited "The Great Recession and Developing Countries: Economic Impact and Growth Prospects". World Bank. Washington DC, pp 235-295

Dornbusch, Rudiger., Sturzenegger, Federico, and Wolf, Holger, (1990). "Extreme Inflation: Dynamics and Stabilization", Brookings Papers on Economic Activity, Volume 21(2), pp. 1-84.

Gokarn, Subir (2011), "The Price of Protein", Macroeconomics and Finance in Emerging Market Economies, Volume 4(2), pp. 327-335.

Gulati, Ashok, and Saini, Shweta (2013), "Taming Food Inflation in India", Discussion Paper No. 4, Commission for Agricultural Costs and Prices.

Imbert, Clément and Papp, John (2015), "Labor Market Effects of Social Programs: Evidence from India's Employment Guarantee," American Economic Journal: Applied Economics, Volume 7(2), pp. 233-63.

Khundrakpam, Jeevan Kumar and Pattanaik, Sitikantha, (2010), "Global Crisis, Fiscal Response and Medium-term Risks to Inflation in India", Reserve Bank of India Occasional Papers Vol. 31, No.2 pp. 1-29

Krugman, Paul (2008), “Grains Gone Wild", New York Times, April 7, 2008.

Kumar, Praduman, Kumar, Anjani, Parappurathu, Shinoj and Raju, S.S., (2011) "Estimation of Demand Elasticity for Food Commodities in India," Agricultural Economics Research Review, Vol. 24(1), pp. 1-24. 
Kumar, Rajiv, Vashisht, Pankaj, and Kalita, Gunajit (2010), "Food Inflation: Contingent and Structural Factors", Economic and Political Weekly, Volume 45(10), pp. $16-19$.

Mishra, Prachi, and Roy, Devesh (2012), "Explaining Inflation in India: The Role of Food Prices", India Policy Forum, Volume 8, edited by Shekhar Shah, Barry Bosworth and Arvind Panagariya, pp. 139-224.

Mittal, Surabhi (2010), "Application of the QUAIDS Model to the Food Sector in India," Journal of Quantitative Economics, Volume 8(1), pages 42-54.

Nanda, S.K., Vishwakarma, R.K., Bathla, H.V.L., Rai, Anil, and Chandra, P. (2012), "Harvest and Post-Harvest Losses of Major Crop and Livestock Produce in India", All India Coordinated Research Project on Post-Harvest Technology, Indian Council for Agricultural Research, Ludhiana

Nair, Sthanu R, and Eapen, Leena Mary (2012), "Food Price Inflation in India (2008 to 2010)", Economic and Political Weekly, Volume 47(20), pp. 46-54.

Planning Commission (2012), Report of the Working Group on Crop Husbandry, Agricultural Inputs, Demand and Supply Projections and Agricultural Statistics for the Twelfth Five Year plan (2012-2017), Planning Commission.

Rajeswaran, S., Naik, Gopal, and Dhas, R. Albert Christopher, (2014), "Rising Milk Price: A Cause of Concern for Food Security", Indian Institute of Management, Bangalore, Working Paper No. 472.

Sargent, Thomas J. and Wallace, Neil, (1981), "Some Unpleasant Monetarist Arithmetic," Quarterly Review, Federal Reserve Bank of Minneapolis, Fall Issue

Sasmal, Joydeb (2015), "Food Price Inflation in India: The Growing Economy with Sluggish Agriculture", Journal of Economics, Finance and Administrative Science, Volume 20(38), pp. 30-40

Wolf, Martin (2008), "Food Crisis is a Chance to Reform Global Agriculture", Financial Times, April 29, 2008

Xie, Jing, Mittelhammer, Ron and Heckelei, Thomas (2004). "A QUAIDS Model of Japanese Meat Demand", presented at 2004 Annual Meeting, American Agricultural Economics Association 


\section{Appendix}

Table A1: Summary Statistics of the Main Variables

\begin{tabular}{|l|ccccc|}
\hline Variable & $\begin{array}{c}\text { Number of } \\
\text { Observations }\end{array}$ & Mean & $\begin{array}{c}\text { Standard } \\
\text { Deviation }\end{array}$ & Minimum & Maximum \\
\hline Domestic Food Inflation (\%) & 60 & 9.708 & 8.495 & -5.512 & 40.171 \\
Demand Supply Gap (Million Tonnes) & 60 & -2.787 & 19.589 & -35.429 & 62.020 \\
MSP Inflation (\%) & 60 & 2.850 & 9.132 & 0.528 & 31.443 \\
Agricultural Wage Inflation (\%) & 66 & 11.205 & 6.626 & 1.680 & 20.013 \\
Global Food Inflation (\%) & 57 & 9.411 & 15.601 & -33.376 & 69.000 \\
Fiscal Deficit (\% of GDP) & 60 & 7.310 & 1.552 & 3.990 & 9.330 \\
\hline
\end{tabular}

